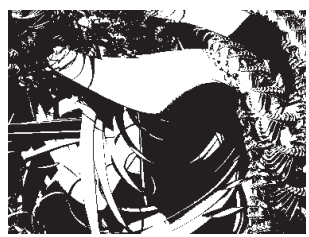

doi:10.5559/di.20.4.03

\title{
IS KNOWLEDGE SOCIETY A VISION OR ILLUSION? THE CASE OF SLOVENIA
}

Maja BUČAR

Faculty of Social Sciences, Ljubliana

UDK: 316.42(497.4):001

Pregledni rad

Primljeno: 4. 2. 2011.

Slovenia put the transition to knowledge economy/society in the centre of its development strategy that is driven by global economic trends and also inspired by the EU Lisbon Strategy. The establishment of a well-functioning national innovation system (NIS) is perceived as the main instrument of the Slovenian transition to knowledge society. The article attempts to analyse some of the elements of NIS and their recent developments to illustrate the main gaps and achievements. The implementation of the major strategic documents driving towards knowledge society in the last five years shows a mixed picture: in some areas the objectives and targets have been achieved, while in others the gaps remain. The article points to the issue of governance capability, which is often forgotten, but is an essential element of the transition. Without improved governance capability the country cannot establish an efficient NIS and consequently move to a knowledge society. This suggests that turning a vision to reality requires significant effort in improving the governance capability.

Keywords: knowledge society/economy, national innovation system, governance capability, Slovenia

$\triangle \quad$ Maja Bučar, Centre of International Cooperation, Faculty of Social Sciences, University of Liubliana, Kardeljeva ploščad 5, 1000 Ljubliana, Slovenia.

E-mail: maja.bucar@fdv.uni-li.si

\section{INTRODUCTION}

Around the turn of the century a new policy context emerged, based on the conviction that the key to facing global challenges consisted of making the transition to a knowledge-based economy through more and better investment in the knowledge 
DRUŠ. ISTRAŽ. ZAGREB GOD. 20 (2011), BR. 4 (114),

STR. $967-990$

BUČAR, $M$.

IS KNOOWLEDGE... triangle of research, education and innovation. Society held high expectations for research as more and better research and development (R\&D) appeared capable of improving economic performance, promoting employment, improving public health, tackling demographic, cohesion and environmental challenges (Felt and Wynne, 2007). A wide-spread belief is that the sustained economic and social development today depends significantly on the continuous creation and application of knowledge. This new emphasis on knowledge is at least in part the result of new growth theories (Romer, 1990; Grossman and Helpman, 1994) and institutional and evolutionary economics (Nelson and Winter, 1982). The first stress the specific character of knowledge and education as intangible productive factors while the latter emphasises the role of innovation as the applied/commercialised knowledge which has boosted the concept of the national innovation system (Nelson, 1993; Lundvall, 1992).

Development strategies, associated with the term knowledge economy/society, are based on observation that fundamental changes are taking place at the level of the economy which are having wide-ranging impacts throughout society and could result in major changes to how people live and work (KEI, 2007). Knowledge includes technical know-how, but also cultural, social and managerial knowledge. This transformation of the structures of the modern economy by knowledge as a productive force constitutes the basis and justification for designating advanced modern society as a "knowledge society". According to Stehr (2003) "Advanced society may be described as a knowledge society because of the penetration of all its spheres by scientific and technical knowledge".

By provision of higher living standards, the use of knowledge supports the development of society as a whole and helps to fulfil social needs. The broader implications of socio-cultural and political transition to a knowledge society and discussion on possible positive and negative developments go beyond the scope of this paper. According to Stehr's terminology, we restrict our discussion to science (not knowledge) policy which is conducted mainly by the national governments and addresses the creation and application of knowledge as a material precondition for development of knowledge society. This course of thinking suggests that a country first needs to establish sufficient capacity for knowledge generation if it wishes to achieve successful transformation towards knowledge society. The science policy develops, thus, many strategies and instruments (tax policies, supporting programmes, subsidised R\&D, etc.) to employ knowledge for economic growth and social development. 
DRUŠ. ISTRAŽ. ZAGREB GOD. 20 (2011),

BR. 4 (114)

STR. $967-990$

BUČAR, M.:

IS KNOWLEDGE..
This paper attempts to assess the transition process towards knowledge society in Slovenia, looking at science and innovation policy, first at various strategy papers and instruments and then at their implementation. The final aims is to assess the success in the implementation of various strategies in order to show the good practices as well as the gaps at the level of indicators, at the level of measures and at the level of policy implementation. The major focus is on the national innovation system, which is assumed to be one of the key pillars of productive use of knowledge for successful transition.

\section{SLOVENIA IN THE CONTEXT OF THE EUROPEAN POLICIES TOWARDS KNOWLEDGE SOCIETY}

While there are certain differences in the scientific literature as to the key elements of knowledge economy/society as well as the drivers to the transition of societies, ${ }^{1}$ a number of important areas are commonly identified and have been addressed by policy makers at various levels - from the World Bank, OECD, EU, to the national states.

Slovenia as an EU member state follows the target of the Lisbon strategy adopted in 2000 which sets the goal of positioning the EU as the world's most competitive and dynamic knowledge-based economy by 2010. Investments in ICT and creation of information society, strengthening research and innovation as well as improvement in higher education and human capital made the three pillars of the EU strategy toward the knowledge society.

By 2004, only four years after the launch of the Lisbon agenda, the assessment of achieved goals (so-called Kok Report: EU, 2004), revealed that in many areas the gap between the planned and implemented activities is significant. Therefore, the EU re-launched the Lisbon strategy in 2005 putting the stress this time on only a few most critical problems - economic growth and new jobs. ${ }^{2}$ During the next three years, the implementation of the Lisbon strategy appeared to have gained in momentum (EC, 2007). However, the EU's economic growth recorded in 2007 (1.8\% since 2005) has been seriously deteriorated by the economic and financial crisis in 2009. In fact, independent evaluations found that the gap between the best and the worst performing countries is wider in 2010 than it was in 2000 (Tilford and Whyte, 2010). The shares of EU in global R\&D in the three main categories - the number of researchers, the investment level and the patent applications have declined (Bučar and Udovič, 2010). In March 2008, the European Council opened a discourse on the future of the Lisbon Process post-2010 and on ways towards a European Globalisation Strategy. As a result, in March 2010, the European 
DRUŠ. ISTRAŽ. ZAGREB GOD. 20 (2011), BR. 4 (114),

STR. $967-990$

BUČAR, $M$.

IS KNOOWLEDGE...
Commission launched the successor of the Lisbon Strategy, a new initiative - "Europe 2020",3 which stresses the need for "smart, sustainable and inclusive growth". According to the "Europe 2020 Integrated Guidelines", each member state is obliged to set out the National Reform Programme (NRP). NRP should set up the national agenda for reforms of the R\&D and innovation systems with special stress on some new issues like smart specialisation, reinforcing cooperation between universities and business, sufficient supply of science, maths and engineering, and so on.

The European "forth and back" towards knowledge society illustrates the complexity and difficulties of building a meaningful strategy and efficient policy for achieving growth based on knowledge. We are in agreement with Mrak (2010) that "creating more favourable framework conditions for private R\&D investment, establishing more appropriate governance structures and the growth of research intensive sectors therefore remain among the key EU objectives in building a knowledge-based economy."

This leads us to our hypothesis that the transition to the knowledge-based economy/society is not so much a technological issue, but above all, a development issue with strong economic, social and cultural dimensions. The changes require a set of much wider socio-economic measures and a coordinated activity of different actors (Bučar and Stare, 2006). They are more difficult to achieve and their implementation is more time-consuming, especially since they require a sufficient level of governance capability. This has often proved to be the key bottleneck in the transition process from traditional industrial society to knowledge society and can be demonstrated at the level of EU or at the level of individual countries. The insufficient governance capability and coordination of policies in the implementation of ERA as a cornerstone of EU strategy in the field of R\&D for transition to knowledge society at EU level was analysed by the Lisbon Expert Group (EC, 2009, 7) and they found that "governance weakness is becoming a key bottleneck preventing the advancement in knowledge policies in Europe".

\section{KEY STRATEGIC DEVELOPMENT POLICY DOCUMENTS}

Slovenia has declared its vision of transforming itself into knowledge society in several of its strategic documents, from Slovenian Development Strategy (SDS-2006-2013; IMAD, 2005), the National Research and Development Programme (NRDP-2005-2010), the National Reform Programme for Achieving the Lisbon Strategy Goals 2005-2010 (Republic of Slovenia, 2005) with 2008 revision (NRP), the National Development Plan (2007-2013) and the 
DRUŠ. ISTRAŽ. ZAGREB GOD. 20 (2011), BR. $4(114)$

STR. $967-990$

BUČAR, M.:

IS KNOWLEDGE.. cuments were prepared nearly simultaneously, they all share a common vision: Slovenia will strive towards transition to knowledge society and focus on all necessary policies to achieve this dynamic transformation. As a member of the EU, Slovenia accepted all the targets set forth in the Lisbon strategy, and made their implementation the backbone of the national strategy papers. One of the important objectives of all the documents was the development of a well-functioning NIS, enabling the transformation to knowledge society.

Specifically for the R\&D and innovation area, the National Research and Development Programme (NRDP, 2006) was prepared in 2005. Key objectives included:

- Increasing of public R\&D investment to 1\% of GDP by 2010;

- Shifting balance of public research funds from basic non-targeted research in favour of targeted (and applied) research;

- Introduction of support measures to stimulate growth of investment of business sector in R\&D to help achieve a $2 \%$ of GDP target;

- Growth of number of researchers with PhDs in the business sector;

- Higher rate of establishment of new high-tech firms, including promotion of spin-offs from universities;

- Continuous participation in the international research, especially in ERA;

- Support to the growth of patents, as an indicator of business relevance of research;

- Growth of high-tech exports and growth of value-added in Slovenian economy.

To be able to draw on the EU Structural funds, Slovenia had to prepare the National Development Programme 2007$2013^{4}$ in 2006. Again, R\&D and innovation were placed highly among the priorities and their key role in achieving the development objectives was clearly spelled out. The activities are to be funded through the projects within first priority of the Operational Programme of European Regional Development Fund "Competitiveness of enterprises and research excellence."5 (NSRF, 2007). The support to joint research and development projects, to the investment in modernisation of intermediary organisations and other institutions in R\&D and for $R \& D$ in business enterprises would enable development of a coherent and efficient NIS and thus provide the basis for knowledge economy/society.

As observed in the beginning, the existing policy documents address the challenges of Slovenian R\&D and innovation system well and set forth clear objectives. In fact, they may even be a bit too optimistic in setting the goals. But policy do- 
cuments are only the broad framework; it is the implementation which reflects the efficacy of innovation policy.

\section{THE CURRENT STATE OF NIS IN SLOVENIA}

A well-functioning NIS in fact requires a strong research \& development (R\&D) system, producing high-quality relevant knowledge, sufficient quality of human resources and innovative entrepreneurs (Lundvall, 1992; Nelson, 1993). The efficiency of NIS depends on the interactions among these different constituting elements, on the quality of each one of them and very much so on the overall socio-political climate. An efficient NIS is, in our opinion, the central element of knowledge society. The country's capability to successfully implement the transition to knowledge society therefore depends on the strength of its NIS.

The Slovenian innovation system has over the years evolved through a complex relationship of a relatively influential public R\&D sector, increasing presence of business as the key investor in $\mathrm{R} \& \mathrm{D}$ and innovation and a search for optimal governance of innovation policy. The country is making slow, but continuous progress in its innovation performance and has, according to the European Innovation Scoreboard joined the countries labelled as innovation followers (EC, 2010). The question is how supportive it is in its current framework for the transition to the knowledge society.

The current state of affairs in building a coherent and well-functioning NIS in Slovenia is a good illustration of the achievements of the country in its transition to knowledge economy.

\section{Basic R\&D and innovation indicators}

In terms of R\&D input indicators (number of researchers, amount of public R\&D investment, level of business R\&D investment), Slovenia scores relatively well in comparison to the EU average. More problematic remains the output side, particularly if measured by number of innovative firms, high tech export or number of patents (EC, 2010). If, according to European Innovation Scoreboard, Slovenia achieved a $6 \%$ rate of growth in enablers, ${ }^{6}$ the progress on the output side shows only $0.5 \%$ growth during the observed period.7 Similarly, Economist Intelligence Unit ranks Slovenia 21st among 82 countries as to the direct inputs in innovation index (R\&D by public and industry sector, educational attainment, IT development), but assesses the innovation environment (political environment, market opportunities, tax system, policy towards entrepreneurship and competition, trade, policy towards FDI, finance, etc.) as low as 45th (EIU, 2009, 12). A possible interpre- 
(1) FIGURE 1

Slovenian R\&D

expenditures in 2009

as per cent of GDP in

comparison with

selected countries tation of these data is that while innovation policy measures can have relatively quick impact on the input side (increased R\&D investment by business sector, for example), the translation of the inputs into noticeable change on the output side, especially in altering the economic structure (employment in high tech manufacturing \& services; export share of high tech), requires a significantly longer time frame.

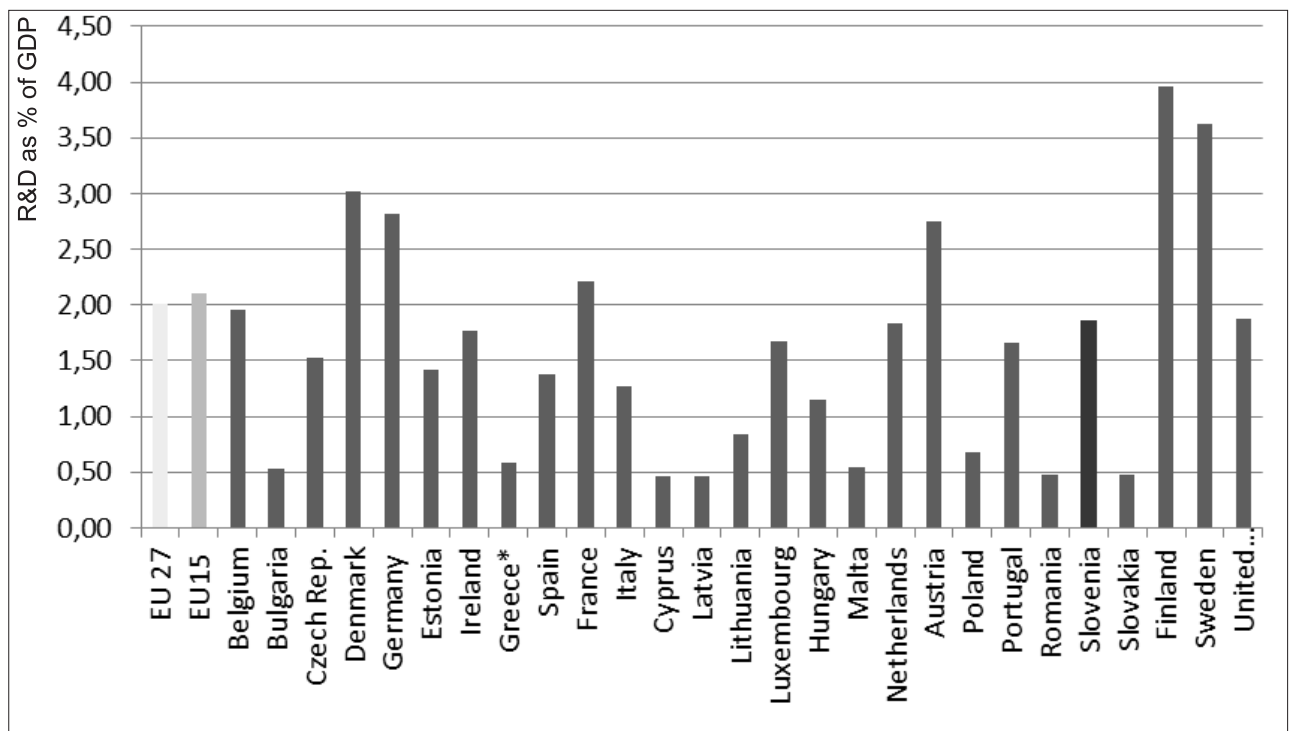

Source: Eurostat (2011): http://appsso.eurostat.ec.europa.eu/nui/print.do?print=true (accessed on Oct 31, 2011).

The level of research and development (R\&D) investment in Slovenia in recent years has been around $1.5 \%$ of the Gross Domestic Product (GDP) for several years now, with small oscillations, but under the EU-27 average. In the year 2009 the percentage was $1.86 \%$ of GDP or 656.9 million EUR for R\&D (SORS, 2011a), up from $1.66 \%$ in 2008 . The amount spent for R\&D in the business sector was $€ 380.9 \mathrm{~m}$, representing a share of $58 \%$, for the first time in several years showing a slight decrease, which is attributed to the financial/economic crisis. The share of government funding of $36 \%$ (€234.2m) of total R\&D expenses reflects an increase over previous years, reflecting the measures undertaken by the government in an attempt to reduce the negative effects of the crisis.

While the figures are relatively impressive if compared with other transition countries, ${ }^{8}$ they remain below the target of $3 \%$ of GDP by 2010, as planned in strategic documents: in fact, their achievement had been postponed to 2013 (Republic of Slovenia, 2008). Except for 2009, when the government committed extra finance for $R \& D,{ }^{9}$ the earlier trends on public $R \& D$ 
(1) TABLE 1

Funding and performing sector in R\&D (2009), final data expenditures were below the planned rate of increase. In view of the financial and economic crisis, the 2009 level was not maintained in the next years: both the 2010 and 2011 preliminary budget figures show a decline in government R\&D expenditures.

\begin{tabular}{lrrrrr}
\hline & \multicolumn{4}{c}{ Performance / Sector } \\
\cline { 2 - 6 } Sources of funds & $\begin{array}{r}\text { Business } \\
(\text { million } €)\end{array}$ & $\begin{array}{r}\text { Government } \\
(\text { million } €)\end{array}$ & $\begin{array}{r}\text { Higher } \\
\text { education } \\
(\text { million } €)\end{array}$ & $\begin{array}{r}\text { Private } \\
\text { non-profit } \\
(\text { million } €)\end{array}$ & $\begin{array}{r}\text { GERD } \\
(\text { million } €)\end{array}$ \\
\hline Total & 424.4 & 136.36 & 95.7 & 0.463 & 656.9 \\
Business enterprises & 355.9 & 15.9 & 8.8 & 0.289 & 380.9 \\
Government & 49.97 & 109.71 & 74.44 & 0.130 & 234.25 \\
Higher education & - & - & 1.9 & - & 1.9 \\
Private non-profit organisations & - & 0.026 & 0.171 & 0.006 & 0.203 \\
Funds from abroad & 18.6 & 10.7 & 10.4 & 0.037 & 39.7
\end{tabular}

Source: SORS (2011a)

What was achieved in line with the strategy papers is the ratio 2:1 between the business and public sector R\&D expenditures. Also, the ratio of government R\&D budget appropriations has changed from 2005 , when $75 \%$ of total resources available for R\&D went for science and only $14 \%$ for technology development, to $60 \%$ for science and $30 \%$ for technology, gradually moving to the targets set in strategic documents. This move was due to several new measures, where co-financing was secured through European cohesion and structural policy funds.

Increased resources resulted in the growth of employment in R\&D, with business sector surpassing the public and higher education in overall employment in R\&D sector, but not yet in terms of number of researchers. In 2008, the total number of R\&D personnel in FTE in the business sector was 6205, of which 3058 were researchers. The government sector and HEI combined employed 5366 personnel (FTE), but 3951 of these were researchers (SORS, 2009).

As for the educational attainment of R\&D personnel, the number of employees with PhD, while on the increase, 10 is still very low in business R\&D - only $10 \%$ of all researchers or 411 in comparison with 1213 in public R\&D institutions and 2452 in HEI.

The increased business investment in R\&D is at least in part the result of a special tax subsidy, which is available since 2006 to the enterprises for R\&D investment. The enterprises can reduce their taxable income for corporate tax by $40 \%$ of their investment in R\&D in general and by an additional 20\% if the investment is made in the regions where the development gap 11 is more than $15 \%$. The tax subsidy was set at $20-40 \%$ ini- 
DRUŠ. ISTRAŽ. ZAGREB GOD. 20 (2011), BR. $4(114)$

STR. $967-990$

BUČAR, M.:

IS KNOWWLEGE..

FIGURE 2

Researchers by sector of employment in FTE tially, but further increased to the current level in 2010 (Official Gazette 43, 2010). The key reason for the increase of subsidy was to prevent a decline in business R\&D investment due to the economic crisis.

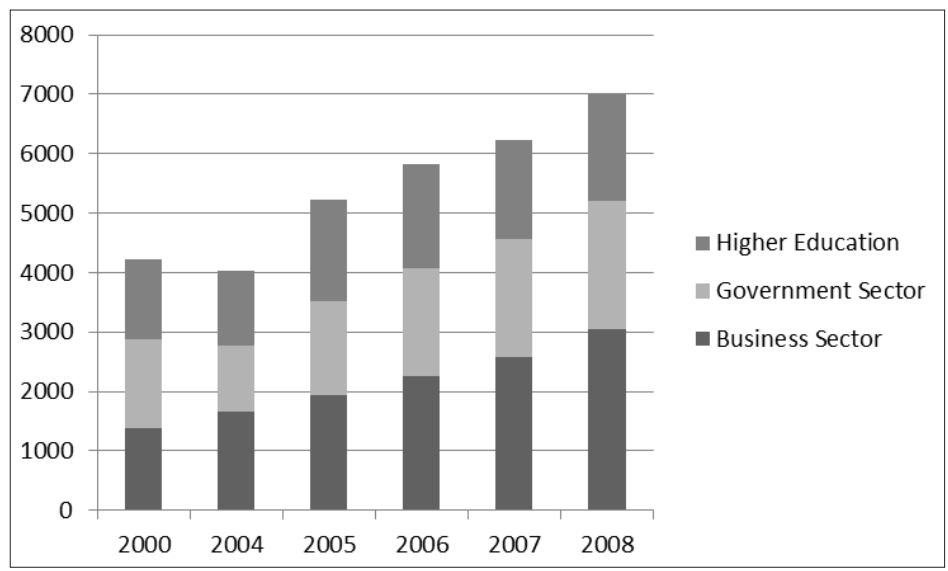

Source: SORS, various years

Most recent data on innovation activity (Community Innovation Survey 2006-2008) is at first glance very positive for Slovenia, since the share of innovation-active firms has increased from $35.1 \%$ during the period 2004-2006 to over 50\% (SORS, 2010b), which would be fully in line with the targets set in strategic documents. Yet the newest survey has applied revised international methodology, where not only technological innovation is included but also non-technological (organisational or marketing) innovation is accounted for. Most of the reporting companies have introduced both, technological and non-technological innovation $(25.2 \%)$, yet if we count these firms together with the ones who only introduced technological innovation $(9.1 \%)$, the total figure is below the $35.1 \%$ of innovation-active firms in 2004-2006. In view of the number of measures, focused on promotion of innovation activity, this result is rather disappointing. Still, the new methodology draws attention to the impact of non-technological innovation, which traditionally has been disregarded in transition economies (Stare and Bučar, 2009).

The degree of innovation cooperation places Slovenian enterprises on the fourth place in EU. According to CIS 2002 2004 and 2004-2006, the cooperation of innovation active enterprises is on the increase in all categories. The most dynamic and closest is the cooperation with the suppliers on one hand and the customers on the other. This could be expected in the production value-chain. The tendency to cooperate in innovation activity is much less pronounced with the small enter- 
DRUŠ. ISTRAŽ. ZAGREB GOD. 20 (2011),

BR. 4 (114),

STR. $967-990$

BUČAR, $M$

IS KNOWLEDGE... prises, which is difficult to explain, since one would assume that it is SMEs who have limited individual capacity to innovate and therefore enter into cooperation with other partners. While $80 \%$ of innovation-active large enterprises have co-operated with other enterprises or institutions, only half as many $(39.6 \%)$ of small enterprises did. Particularly low is the cooperation of SMEs with government or public research institutes: only $9.1 \%$ of respondents have cooperated with them. In the case of higher education sector, the cooperation was reported by $13.6 \%$ of SMEs. ${ }^{12}$ Yet, our research, based on case studies, has shown that several successful companies, regardless of their size, have established links with public research either at universities or research institutes and formed permanent teams of researchers from both sides. According to their statements, it took some time to find a common language and to develop fruitful cooperation, but in the end, the result is beneficial to both sides (Bučar and Rojec, 2009).

\section{Support institutions}

Over the years, Slovenia has developed a rather complex scheme of institutions for R\&D and innovation policy implementation, set up with the ambition to provide as complete innovation system as possible. The support institutions can be grouped according to their main tasks in the following categories:

a) Government executing/funding agencies: Slovenian Research Agency, Slovenian Technology Agency, Public Agency for Entrepreneurship and Foreign Investment, Slovenian Enterprise Fund.

b) 'Bridging' and support institutions like technology centres, technology platforms, centres of excellence, clusters, technology parks, business and university incubators, technology transfer offices, VEM-points, ${ }^{13}$ regional development agencies, etc.

c) Financial intermediaries: venture capital funds, business angels association, etc.

The relatively extensive support network is often criticised for its low effectiveness due to insufficient coordination and specialisation, with no clear demarcation of the tasks. The challenge of coordinated approach to designing the most efficient network, combining the roles of various institutions in a coherent and transparent support system remains a difficult but urgent task for the policy makers, since the intermediate institutions are an important element of the knowledge-supportive NIS. Their task of disseminating knowledge through the economy/society is crucial for knowledge society and if 
they are not well co-ordinated and provide suboptimal support, they are a barrier instead of promoter of the transition.

\section{Institutional setting and policy measures}

The institutional framework of innovation policy with its relatively frequent changes since Slovenia's independence reflects the search for the most efficient division of tasks between different ministries. Each of the past elections had brought forward new ideas on how to best organise the government to be more supportive to science, technology and innovation. Since 2008, the innovation policy is the responsibility of the Ministry of Higher Education, Science and Technology, the Ministry of Economy and to some extent also the two Government Offices: the Office for Development and European Affairs and the Office for Local Self-Government and Regional Development. All of these bodies also have responsibilities in the implementation of the strategic policy documents, related to the Lisbon strategy and transition to knowledge society. This suggests strong integration of innovation in the transition process.

In the innovation system so far the support to $R \& D$, especially public $R \& D$, has been seen as the most important objective. However, following the line of the Lisbon strategy and especially due to the significant amount of additional resources coming from the EU Structural funds, the business related R\&D measures have gained in their importance since 2008. Several new measures were introduced: from strategic research and investment projects (RIPs) to centres of excellence and most recently, centres of competence. The values of those programmes are significant for Slovenian R\&D. They range from 1 million EUR (RIPs) to nearly 10 million EUR (centres of excellence) and provide important new R\&D capacity. What will the impact of these measures be on the generation of new knowledge and the effectiveness of NIS is as yet too early to speculate.

In view of the increased available resources, a close monitoring of the absorption capacity of the business sector is required. Also the ability of public R\&D to deliver effectively the support under existing policy measures should be regularly assessed. A positive sign is that the evaluation and reporting practice has significantly improved over the recent years, since most of the agencies or the ministries, which have to report on the use of the European funds have increased their attention to evaluation and several of the new measures have stipulated from the start the regular evaluation intervals (for example, the centres of excellence have to be evaluated annually). 


\section{Human resources for NIS/knowledge society}

The issue of sufficiently educated and trained human resources is one of the central topics for the future development of Slovenian NIS and consequently of knowledge society. Not only is it important from the viewpoint of having an adequate supply of new researchers, but equally so in raising the educational attainment of the entrepreneurs in SMEs and the overall educational level of citizens. Slovenia has in 2010/2011 surpassed its target of enrolling more than half of the respective generation in tertiary education (IMAD, 2011). The number of students enrolled in tertiary education relative to the number of the population aged 20-26 increased from 29.9\% in 2000 to $41 \%$ in $2008 / 2009$. As noted by IMAD (2010), in the academic year 2008/2009, participation of the generation at enrolment age in tertiary education $(53.1 \%$ ) was close to the Slovenian Development Strategy target (55\%). Even though the enrolment in Science \& Technology programmes has been promoted heavily, Social sciences and humanities still remain the most popular choice and attract as many as $43 \%$ of all enrolled. This can be seen also in the percentage of SSH graduates, representing a share of $44 \%$ of all graduates and Arts programmes, most of them from law and business studies (SORS, 2011b).

The increase in the enrolment was not followed by an adequate increase in the number of teaching staff. Slovenia still lags considerably behind most European countries. The ratio in Slovenia is also worsened by the fact that young people not only enrol in tertiary education to acquire education but also to take advantage of the benefits of being a student. ${ }^{14}$ This is further reflected in low efficiency of studies. The average duration of studies of full-time university graduates is among the highest in Europe. In 2008, the average duration was 6.7 years (2007: 6.8 years). ${ }^{15}$ The low efficiency of studies is also seen by comparing data on the number of students in tertiary education per 1.000 population aged 20-29, where Slovenia is well above the EU average, ${ }^{16}$ with data on the number of graduates of tertiary education per 1.000 population aged 20-29, where Slovenia lags behind the EU average. ${ }^{17}$

\section{KEY INDICATORS FOR THE KNOWLEDGE ECONOMY/SOCIETY}

An assessment of what was achieved during the five years of the implementation of strategic documents revealed mixed results. In some indicators, Slovenia is meeting the targets; in some the gaps are just as big as they were at the beginning of the envisaged transition to knowledge society. For a more objective picture, it is relevant to see, how the country compares with others. 
DRUŠ. ISTRAŽ. ZAGREB GOD. 20 (2011), BR. $4(114)$

STR. $967-990$

BUČAR, M:

IS KNOWLEDGE..

(1) FIGURE 3

Basic Scorecard for Slovenia (2009)
Two different systems of comparison are considered: one is the Knowledge Economy Index developed by the World Bank. The KAM 18 consists of 109 structural and qualitative variables for 146 countries to measure their performance on the $4 \mathrm{Know}$ ledge Economy (KE) pillars: Economic Incentive and Institutional Regime, Education, Innovation, and Information and Communications Technologies. According to the latest available data (2009), Slovenia is ranked as the 25th country in the world.

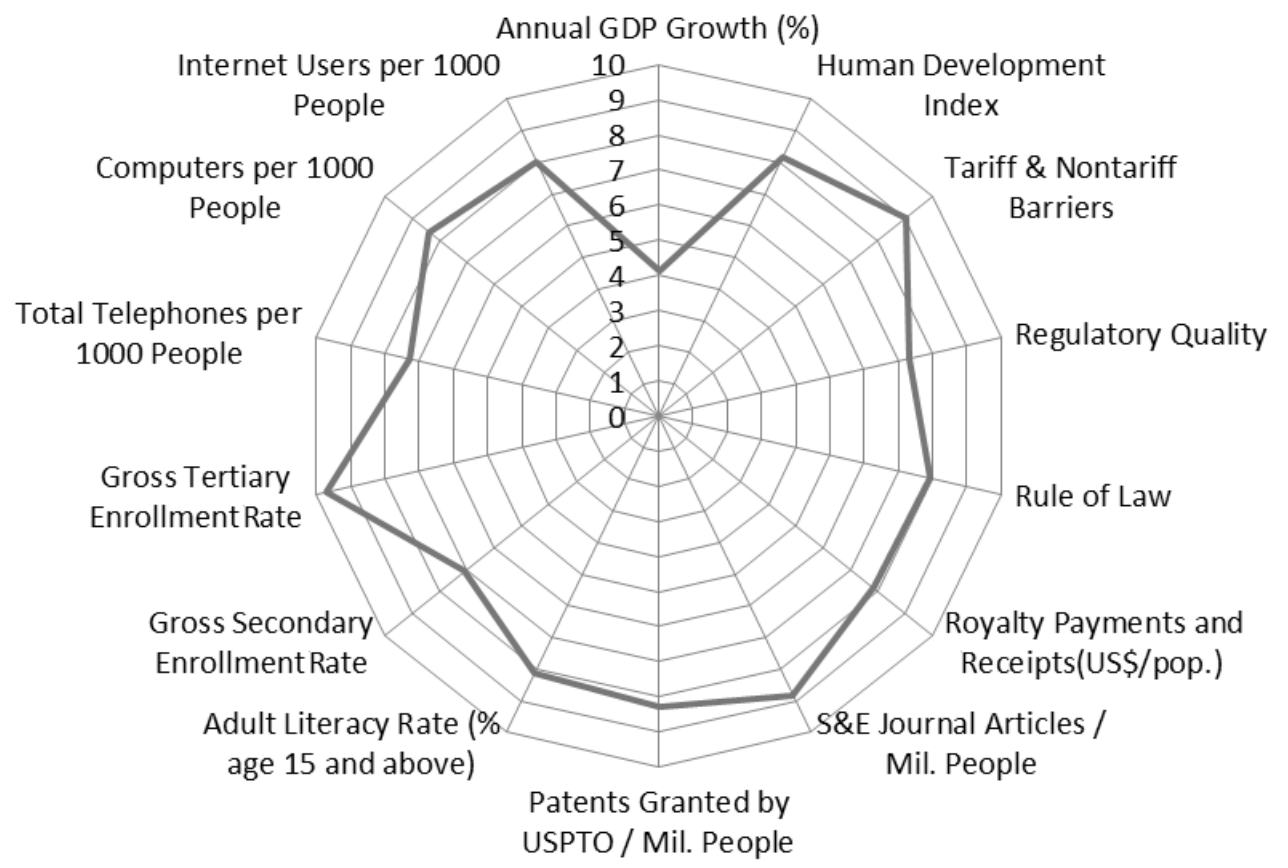

Source: http://info.worldbank.org/etools/kam2/KAM_page2.asp (Oct. 28, 2011)

The graph above shows the position of Slovenia according to the main indicators of KEI in comparison to all countries included in the database. What is informative is the progress achieved from 1995 in overall KEI as well as in individual groups of indicators. In overall KEI, practically no progress has been made $(+0.03)$. In terms of individual groups, catching up can be noticed in the area of economic incentives and institutional regime $(+0.89)$, slight progress in innovation $(+0.33)$ and education $(+0.38)$ and a substantial fall-back in ICT area (-1.74).

Extensive research on indicators was carried out also within EU FP6 project on Knowledge Economy Indicators. ${ }^{19}$ The project's aim was to develop and improve indicators for the knowledge economy, including the analysis of aggregation is- 
DRUŠ. ISTRAŽ. ZAGREB GOD. 20 (2011) BR. $4(114)$

STR. $967-990$

BUČAR, $M$.

IS KNOWLEDGE...
(1) FIGURE 4

Knowledge

Economy Index sues and the use of composite indicators. The project has covered indicators from 25 European countries (the EU-25) and two non-European countries (the US and Japan). A total of 115 individual indicators have been selected to measure the sub-dimensions of the knowledge-based economy (KBE) and grouped under the seven main dimensions: ${ }^{20}$

- $\quad$ production and diffusion of ICT;

- human resources, skills and creativity;

- knowledge production and diffusion;

- innovation, entrepreneurship, creative production;

- economic outputs;

- $\quad$ social performance and

- internationalisation.

The composite Knowledge Economy Index was then calculated as well as ranking according to each of the seven main groups and all of the 115 indicators produced (KEI, 2008, WP 8).

Knowledge Economy Index

Rank

$\begin{array}{lllllllllllllllllllllllllllll}1 & 2 & 3 & 4 & 5 & 6 & 7 & 8 & 9 & 10 & 11 & 12 & 13 & 14 & 15 & 16 & 17 & 18 & 19 & 20 & 21 & 22 & 23 & 24 & 25 & 26 & 27 & 28 & 29\end{array}$

Sweden $\quad 54 \quad 46$

Denmark $\quad 55 \quad 30 \quad 14$

$\begin{array}{llllllllll}\text { Luxembourg } & 36 & 4 & 14 & 25 & 4 & 7 & 7 & 4\end{array}$

Finland $\quad \begin{array}{lllllll}18 & 23 & 29 & 9 & 11 & 11\end{array}$

$\begin{array}{llllllll}\text { USA } & 11 & \underline{32} & 2 & 4 & \underline{39} & 9 & 4\end{array}$

Japan $\quad 4 \quad 7 \quad \begin{array}{lllll}38 & \underline{32} & \underline{36}\end{array}$

UK $\quad 2 \quad 5 \quad 16 \quad 38 \quad 39$

Netherlands

Ireland

Austria

Belgium

France

EU15

EU25

Germany

Slovenia

Estonia

Malta

Cyprus

Spain

Czech. Rep.

Latvia

Italy

Greece

Lithuania

Hungary

Portugal

Slovakia

$\begin{array}{lrrrrrrr} & 86 & 4 & & 4 & & & 7\end{array}$

$\begin{array}{lllll}18 & 50 & 18 & 7 & 7\end{array}$

$\begin{array}{llllll}11 & 4 & \overline{11} & 57 & 16 & 2\end{array}$

$\begin{array}{llll}14 & 18 & 11 & 54\end{array}$

$\begin{array}{llll}4 & 57 & \underline{39}\end{array}$

$\begin{array}{llllll}4 & 4 & 14 & \underline{32} & \underline{39} & 7\end{array}$

$\begin{array}{rrrr}79 & 4 & 7 & 4\end{array}$

$\begin{array}{llll}7 & \underline{41} & \underline{38} & 14\end{array}$

$\begin{array}{llllll}4 & 36 & 25 & 21 & 11 & 4\end{array}$

$\begin{array}{lllllll}7 & 13 & 9 & 21 & 23 & 27\end{array}$

$\begin{array}{llrlll}\underline{36} & 7 & 4 & 23 & 23 & 7\end{array}$

$\begin{array}{llllll}4 & 4 & 32 & 25 & 29\end{array}$

$\begin{array}{lllllll}4 & 7 & 30 & 39 & 5 & 7 & 7\end{array}$

$\begin{array}{llllll}20 & \underline{36} & 11 & 21 & 7\end{array}$

$\begin{array}{llllll}29 & 18 & 9 & 29 & 9 & 7\end{array}$

$\begin{array}{llllllll}4 & 4 & 4 & 29 & 18 & 21 & 7 & 14\end{array}$

$\begin{array}{lllll}4 & \underline{41} & 13 & \underline{32} & 11\end{array}$

$\begin{array}{lllllll}\frac{41}{2} & 13 & \frac{32}{13} & 57 & 2 & 14\end{array}$

$\begin{array}{lllll}4 & 7 & 11 & 61 & 14\end{array}$

$\begin{array}{llll}4 & 7 & 18 & \mathbf{7 1}\end{array}$

Poland

Legend: frequency lower 15\%, frequency between 15 and 30\%, frequency between 30 and $50 \%$, frequency greater than $50 \%$. Source: http://www.uni-trier.de/fileadmin/fb4/projekte/SurveyStatisticsNet/KEI-WP5-D5. 8etal. pdf, p. 11.

Slovenia found itself in 16-17th place with most of the indicators. The values for 7 indicators would put the country higher than this rank. On the other hand, in 14 indicators the 
DRUŠ. ISTRAŽ. ZAGREB GOD. 20 (2011), BR. 4 (114)

STR. $967-990$

BUČAR, M.:

IS KNOWLEDGE... country's position is lower than this ranking. Interestingly, when the authors calculated the ranking according to individual dimension, Slovenia scored best in social performance (11th place) and worst in internationalisation (20-21st place). In terms of indicators, related to NIS, the ranking was rather stable: around 14 to 19th place, close to the EU25 average, which would be a corresponding score for Slovenia in the already mentioned European Innovation Scoreboard.

Taking on board warnings of methodology problems with composite indicators and missing data, we can conclude that our assessment is confirmed by these rankings as well: Slovenia's performance is mixed-some indicators show progress, while others need to be substantially improved if the vision of knowledge society is to become a reality. What seems to stand out as a particular problem is not the setting of the strategy or design of the appropriate measures of innovation policy per se, but the implementation of the broader socio-economic policies, related to effective functioning of the national innovation system. If the national innovation system is to support the transition to the knowledge economy/society, it needs to be well integrated in the overall development policy-setting with strong horizontal and vertical linkages. This goes much beyond "simple" design of R\&D and innovation policy, but touches upon the broader issue of governance capability.

\section{THE IMPORTANCE OF GOVERNANCE CAPABILITY FOR KNOWLEDGE SOCIETY}

Governance comprises "all those activities of social, political, and administrative actors that can be seen as purposeful efforts to guide, steer, control or manage sectors or facets of societies" (Kooiman, 2003). Governance is an interactive process involving various forms of partnerships, collaboration, competition and negotiation. It implicitly addresses the issue of accountability, lack of transparency and representation, all of which may create weaknesses (OECD, 2005, 24). European Commission's White Paper on Governance (EC, 2001) sets out five principles that underpin good governance. They are: openness, participation, accountability, effectiveness and coherence. These are required for the sound management of public resources and essential in creating environment conducive to business, as well as a productive partnership between public and private sectors.

Innovation governance incorporates a broad set of mechanisms, instruments and institutions in the field of R\&D, education, and entrepreneurship. It focuses on the interplay between the various actors that together determine the priorities, strategies, activities and outcomes in innovation (Boekholt, 2004). Successful governance requires, among others, co- 
DRUŠ. ISTRAŽ. ZAGREB GOD. 20 (2011), BR. 4 (114),

STR. $967-990$

BUČAR, M.

IS KNOOWLEDGE... ordination and interaction across different organisations affecting innovation capabilities: we talk of horizontal and vertical coherence of innovation policy. Horizontality of innovation policy in practice means that all the measures introduced in other policy areas (for example in fiscal policy or in educational policies) are checked for their impact on innovation (EC, 2003). On the other hand, the vertical coherence relates to coordination of policies among different levels of actors (national, regional) in the field of innovation.

The governance capability in the area of innovation policy is crucial for success in further design and implementation of publicly funded measures and their impact on the economy. The effectiveness of influencing the innovation capabilities and behaviour of enterprises relies on the "governance" of R\&D and innovation policies (EC, 2003).

In the case of Slovenian development of NIS, insufficiently developed governance capability can be detected in the introduction of overlapping policy measures, insufficient transparency of support institutions or in poorly adjusted mechanisms, transferred from other countries (EU, 2009). In several cases, there is significant discrepancy between the policy papers to the actual practice: while in all of the cited strategic papers innovation is highly praised, the public budget allocation did not follow this praise. This results in the so called "implementation deficit", where several well-designed innovation support measures never become operational or were put in place with insufficient resources ${ }^{21}$ (Bučar, 2009).

Building the innovation capacity in terms of sufficient number of enterprises engaged in innovation activity as well as governance capability requires a long-term effort, which needs to move beyond institutional build-up. The setting up of the institutions and policy measures are the first steps only, which need to be followed by the creation of efficient policy mix, focused on the major gaps in innovation capacity. Frequent changes in the institutional set-up, in the responsibilities and roles of different public agents as well as in changing measures, have undermined the governance capability in innovation policy and created a fragmented innovation support system, which not only is difficult to manage, but is also unfriendly towards those it should be benefiting.

Attainment of governance capacity is a long-term process, and the complexities should not be underestimated.

\section{CONCLUDING THOUGHTS}

In the long run, a small economy such as the Slovenian, with ambitions to build a knowledge society, can do this only with an efficient national innovation system. Slovenia will therefore need to change its mode of functioning and "move from routine to innovation" (Mulej et al., 1994) and win its position 
DRUŠ. ISTRAŽ. ZAGREB GOD. 20 (2011), BR. $4(114)$

STR. $967-990$

BUČAR, M.:

IS KNOWLEDGE.. not only within the EU but also within the global division of labour. Unless this change happens, the country faces the danger of a laggard and the living standard of our citizens would reflect this. In this process of catching up, further promotion of human resources build-up and a modern R\&D sector as well as of widespread innovation activity in private and public sectors could be used as strategic "tools", if integrated into the overall national development strategy.

The analysis of countries that were successful in the past in catching-up with more developed countries by leap-frogging certain development stages shows that this was never achieved without a conscious action of the government. ${ }^{22}$ The transformation of R\&D and educational systems towards innovation does not occur by spontaneous activity of the free market or even by increased investment in R\&D. Contrary to this, the very nature of innovation as an endogenous process calls for the type of economic growth which is embedded in the overall social, cultural and institutional framework of a country (Švarc, 2006, 337). A pro-active role of the government as well as of broader society is therefore needed, or in the words of Abramovitz (1986) sufficient "social capability", which in turn determines the ability for technological and structural transformation of a country and thus opens up the possibility for catching up and a transition to knowledge-based economy/society.

For a vision to become a reality, good strategy is an important starting point, but the governance capability to engage all stakeholders in a coordinated manner in the implementation process is essential. The issue of governance capability should not be underestimated in these processes. Both, the EU implementation of the Lisbon process as well as Slovenian transition to knowledge society as conceptualised in the strategic documents show that it is the governance capability which is detrimental to the success. Partial policies, no matter how well designed, cannot bring about the overall change. This should be observed by other transition societies as well: to decide on a strategy is only the first and probably the least difficult step towards the knowledge society, the ability to implement this structural change is where the difficult challenges lie.

\section{NOTES}

1 A good overview of different issues related to knowledge society/ economy is provided in the paper "The puzzle of knowledge society" by European Foundation for the Improvement of Living and Working Conditions (Eurofound, 2004).

2 On this basis the EC published the Integrated Guidelines for Growth and Jobs 2005-2008; available at http://ec.europa.eu/growthandjobs/ pdf/integrated_guidelines_en.pdf.

3 Available at: http://ec.europa.eu/europe2020/index_en.htm. 
DRUŠ. ISTRAŽ. ZAGREB GOD. 20 (2011), BR. 4 (114),

STR. $967-990$

BUČAR, $M$. IS KNOOWLEDGE...
4 Rep. of Slovenia (2007) Office of Government for Local Self Government and Regional Policy. See more at: http://www.svlr.gov.si/si/ delovna_podrocja/drzavni_razvojni_program.

5 Operativni program krepitve regionalnih razvojnih potencialov 2007-2013. (Operational Programme for strengthening regional development potentials 2007-2013.) Available at: http://www.svlr.gov.si/fileadmin/svlsrp.gov.si/ pageuploads/KOHEZIJA/OP_RR_USKLA-JENO_08_06_07_poslano.pdf.

${ }^{6}$ EIS groups indicators in three segments: enablers (human resources and public R\&D investment), firm activities (business sector investment in R\&D\& innovation cooperation, patents and technology balance of payment) and outputs (number of new products on the market, high tech export and employment, etc.).

7 One also needs to take into consideration the fact that for several output indicators no (recent) data is available.

8 Udovič and Bučar found $(2008,36,38)$ that between 1995 and 2005 Slovenia led among NMS in GERD (which amounted to nearly $300 \%$ of GERD in Slovakia or Poland) and in BERD, which was already in 2004, for example, four times bigger than Slovak.

9 The first revision of the budget (April 2009) added new resources for R\&D and innovation, so the total allocation was planned at 370 million $€$. Yet due to the deepening of the economic crisis, the second revision of the budget for 2009 took place in July 2009, and the amount for R\&D and innovation was revised downward to 335 million $€$. This figure still represented an increased amount available for technological restructuring of the business sector (see details in EU, 2010).

10 From 2006 the number has increased by 37\% (SORS, various years). 11 Development gap is calculated as the difference between the average per capita income in Slovenia and the income achieved in particular region.

12 On the other hand, large firms cite $38.8 \%$ of cooperation with public research institutes and as much as $53.8 \%$ of cooperation with HEI.

13 VEM-points (vse na enem mestu - all in one place) were established to provide a single entry point for new enterprises, where complete information required for setting up business is provided.

14 Additional explanation for the long time required to graduate is the benefits enjoyed by the legal status of students (e.g. students can work with no income tax while employers do not need to pay social and health security compulsory contributions. In addition, such employment provides for high level of flexibility in hiring, since this is typically a temporary engagement. The government proposed a new law on regulating this type of employment in spring 2010, which resulted in loud opposition by the student organisations.

15 Data from EUROSTUDENT III (2005-2008), available for 2006 or 2007.

16 In 2007, the ratio in Slovenia was 40.1, the EU average was 28.6 (IMAD, 2010).

17 In Slovenia, the number of graduates in tertiary education per 1.000 population aged 20-29 was 57.7 (EU-27: 59.9). 
DRUŠ. ISTRAŽ. ZAGREB GOD. 20 (2011), BR. 4 (114) STR. $967-990$

BUČAR, M.: IS KNOWLEDGE..
18 http://web.worldbank.org/WBSITE/EXTERNAL/WBI/WBIPRO GRAMS/KFDLP/EXTUNIKAM/0,,menuPK:1414738 pagePK:641684 27 piPK:64168435 theSitePK:1414721,00.html.

19 C1S8-CT-2004-502529 KEI; http://www.uni-trier.de/index.php? $\mathrm{id}=26661$.

20 Details on the methodology and the approach to construction of the Index can be found at http://www.uni-trier.de/fileadmin/fb4/ projekte/SurveyStatisticsNet/KEI-WP5-D5.8etal.pdf.

21 One such case is the creation of the Slovenian Innovation Agency, which was proposed by a PHARE project in 1999, accepted by the government, but never implemented. A similar story was with the university incubators: as suggested by the PHARE 2003 study, the support measure for university incubators was introduced in 2004. Yet after the initial enthusiasm, the incubators ran into serious trouble because the administrative procedure for the preparation of the public call under the PHARE programme delayed the payment of funds and nearly caused the bankruptcy of the incubators (EU, 2006).

22 Freeman (1989) points out the complexity of such undertakings: The success of any country to catch-up within the next decades depends crucially on their ability for institutional innovation, infrastructure, investment in education, S\&T and last, but not least, on the international economic system.

\section{REFERENCES}

Abramovitz, M. (1986), Catching Up, Forging Ahead and Falling Behind. Journal of Economic History, 46 (2): 385-406. doi:10.1017/S00 22050700046209

Boekholt, P. (2004), Ensuring Policy Coherence by Improving the Governance of Innovation Policy, Trend Chart Policy Workshop Background Paper, Brussels: EC, http://trendchart.cordis.lu/reports/documents/ WKS1_backgroundpaper.pdf.

Bučar, M. and Udovič, B. (2010), Slovenia and the Lisbon Strategy: A Road to Knowledge Economy? In: P. Drulák and Z. Šabič (Eds.), The Czech and Slovenian EU Presidencies in a Comparative Perspective (European Union Studies Library, 1) (pp. 145-162), Dordrecht, Republic of Letters.

Bučar, M. (2009), ERAWATCH COUNTRY REPORT 2009: Slovenia. Analysis of Policy Mixes to Foster RED Investment and to Contribute to the ERA. Available at: http://cordis.europa.eu/erawatch/index.cfm?fuseaction $=$ reports.content\&topicID=600\&parentID=592 (20th October 2009).

Bučar, M. and Stare, M. (2006), From Quantity to Quality: Critical Assessment of Slovenia's Potential for Knowledge-Based Growth. In: K. Piech and S. Radošević (Eds.), The Knowledge-Based Economy in Central and Eastern Europe: Countries and Industries in a Process of Change (pp. 239-255), Basingstoke and New York, Palgrave Macmillan.

Bučar, M. and Rojec, M. (2009), Cases of Science-Industry Cooperation in Slovenian Food and Chemical Industries, Ljubljana, Faculty of Social Sciences. 
DRUŠ. ISTRAŽ. ZAGREB GOD. 20 (2011), BR. 4 (114),

STR. $967-990$

BUČAR, $M$ :

IS KNOOWLEDGE...
EC (2001), European Governance - White Paper; COM (2001) 428 Final. EC (2003), Innovation Policy: Updating the Union's Approach in the Context of the Lisbon Strategy, Communication from the Commission COM (2003) 112, Brussels: EC.

EC (2007), Strategic Report on the Renewed Lisbon Strategy for Growth and Jobs: Launching the New Cycle (2008-2010). Keeping up the Pace of Change, COM (2007(803)). Available at: http://ec.europa.eu/growth andjobs/pdf/european-dimension-200712-annual-progress-report/ 200712-annual-report_en.pdf.

EC (2009), The Governance Challenge for Knowledge Policies in Lisbon Strategy: Between Revolution and Illusion; Synthesis Report of Expert Group for the Follow-Up of the Research Aspects of the Revised Lisbon Strategy; European Commission DG Research.

EC (2010), European Innovation Scoreboard 2009 Comparative Analysis of Innovation Performance, INNO Metrics. Available at: http://www.proinno-europe.eu/page/european-innovation-scoreboard-2009.

EIU - Economist Intelligence Unit (2009), A New Ranking of the World's Most Innovative Countries; An EIU Report, April 2009, sponsored by Cisco. Available at: http://graphics.eiu.com/PDF/Cisco_Innovation_ Complete.pdf.

EU (2004), Report from the High Level Group Chaired by Wim Kok (Kok Report) (2004) Facing the Challenge: The Lisbon Strategy for Growth and Employment. Available at: http://ec.europa.eu/growthandjobs/pdf/ kok_report_en.pdf.

EU (2006), PRO INNO Innovation Trend Chart on Innovation: Country Report on Slovenia 2005

EU (2009), PRO INNO Innovation Trend Chart on Innovation: Country Report on Slovenia 2008. Available at: http://www.proinno-europe.eu/ trendchart/annual-country-reports.

EU (2010), PRO INNO Innovation Trend Chart on Innovation: Country Report on Slovenia 2009. Available at: http://www.proinno-europe.eu/ trendchart/annual-country-reports.

Eurofound (2004), The Puzzle of Knowledge Society. Paper presented at the Irish Presidency Conference "Foresight for Innovations - Thinking and Debating the Future: Shaping and Aligning Policies", Dublin, 14-15 June 2004. Available at: http://www.eurofound.eu.int/ areas/industrialchange/knowledgesociety.htm.

European Council (2000), Lisbon European Council, Presidency Conclusions, March 2000. Available at: http://www.aedh.eu/plugins/ fckeditor/ userfiles/file/DESC/2000\% 20LISBON\% 20EUROPEAN\% 20COUNCIL \% 2023\% 20AND\% 2024\% 20MARCH.pdf.

Eurostat (2010), Data available on the webpage of the EUROSTAT. Available at: http://epp.eurostat.ec.europa.eu/portal/page/portal/euro stat/home.

Eurostat (2011), Data available on the webpage of the EUROSTAT. Available at: http://appsso.eurostat.ec.europa.eu/nui/print.do?print= true.

Felt, U. and Wynne, B. (Eds.) (2007), Taking European Knowledge Society Seriously. Report of the Expert Group on Science and Governance to the 
DRUŠ. ISTRAŽ. ZAGREB GOD. 20 (2011), BR. 4 (114),

STR. $967-990$

BUČAR, M.: IS KNOWLEDGE..
Science, Economy and Society Directorate, Directorate-General for Research, European Commission. Luxembourg: Office for Official Publications of the European Communities, http://ec.europa.eu/research/ science-society/document_library/pdf_06/european-knowledgesociety_en.pdf.

Freeman, C. (1989), New Technology and Catching Up. The European Journal of Development Research, 1 (1): 85-99. doi:10.1080/0957881890 8426503

Grossman, G. M. and Helpman, E. (1994), Endogenous Innovation in Theory of Growth. Journal of Economic Perspectives, 8 (1): 23-44. doi: 10.1257/jep.8.1.23

IMAD (2005), Slovenian Development Strategy. Ljubljana, IMAD. Available at: http://cordis.europa.eu/erawatch/index.cfm?fuseaction = policy.documentAjax\&uuid =7D87A4CA-C30B-7F76-24B2D3F6E 1735FDE (20th October 2009).

IMAD (2010), Development Report 2010. Available at: http://www.umar. gov.si/en/publications/?no_cache $=1$.

IMAD (2011), Development Report 2011. Available at: http://www.umar. gov.si/en/publications/single/publication/zapisi/porocilo_o_razvoju 2011/5/?tx_ttnews[syear] $=2011 \&$ tx_ttnews[scat] $=5 \& \mathrm{cHash}=8 \mathrm{c} 0 \mathrm{bc} \overline{\mathrm{f}}$ $3 \mathrm{c} 7$.

KEI (2007), Knowledge Economy Indicators. Workpackage 1: State-of-theArt on the Knowledge-Based Economy, http://kei.publicstatistics.net/.

KEI (2008), Workpackage 8: An Overview of the KEI Achievements; CIS $8\{\mathrm{CT}\{2004\{502529 \mathrm{KEI}, \mathrm{http}: / /$ kei.publicstatistics.net/.

Kooiman, J. (2003), Governing as Governance, London, Sage Publications, Thousand Oaks and New Delhi.

Lundvall, B.-Å. (Ed.) (1992), National Systems of Innovation: Towards a Theory of Innovation and Interactive Learning, London, Pinter Publishers.

MHEST (2010), Osnutek Nacionalnega programa visokega šolstva (Draft Programme on Higher Education). Available at: http://www.mvzt.gov.si/ si/zakonodaja_in_dokumenti/nacionalna_programa_v_pripravi/ javna_razprava_o_osnutku_npvs_2011_2020/

Mrak, M. (2010), The Post-Lisbon-Type Strategy - Perspectives and Challenges. In: V. Samardžija and H. Butković (Eds.), From the Lisbon Strategy to Europe 2020 (pp. 66-80), IMO, Zagreb.

Mulej M., Hyaeverinen, L., Jurše, K., Rafolt, B., Rebernik, M., Sdevčič, M. and Uršič, D. (1994), Inovacijski management, Maribor, Ekonomsko-poslovna fakulteta.

Nelson, R. R. (1993), National Innovation Systems: A Comparative Analysis, Oxford, Oxford University Press.

Nelson, R. R. and Winter, S. G. (1982), An Evolutionary Theory of Economic Change, Cambridge Mass. and London, England, Harvard University Press.

NRDP (2006), National Research and Development Programme. Available at: http://www.uradni-list.si/1/content?id=67936 (20th October 2009).

NSRF (2007), National Strategic Reference Framework. Available at: http:// www.svlr.gov.si/fileadmin/svlsrp.gov.si/pageuploads/KOHEZIJA/Pro gramski_dokumenti/NSRF_Slovenia_18_06_07_Unoff_eng_trasl.pdf. 
DRUŠ. ISTRAŽ. ZAGREB GOD. 20 (2011), BR. 4 (114),

STR. $967-990$

BUČAR, $M$ :

IS KNOOWLEDGE...
OECD (2005), Governance of Innovation Systems, Vol. 1: Synthesis Report, Paris, OECD.

Official Gazette of the Rep. of Slovenia, 2010, No. 43/2010, from 31. 5. 2010. Available at: http://www.uradni-list.si/1/index?edition $=201043$

Operativni program krepitve regionalnih razvojnih potencialov 2007-2013. (Operational Programme for Strengthening Regional Development Potentials 2007-2013. Available at: http://www.svlr.gov.si/fileadmin/svlsrp.gov.si/ pageuploads/KOHEZIJA/OP_RR_USKLA-JENO_08_06_07_poslano.pdf. Republic of Slovenia (2005), National Reform Programme for Achieving the Lisbon Strategy Goals. Available at: http://www.umar.gov.si/fileadmin/ user_upload/projects/04_alizb-strategija.pdf.

Republic of Slovenia (2007), National Development Programme 2007-2013. Ljubljana, Office of Government for Local Self Government and Regional Policy.

Republic of Slovenia, Office for Growth (2008), National Reform Programme for Achieving the Lisbon Strategy Goals - Implementation Report. Available at: http://www.svr.gov.si/fileadmin/srs.gov.si/pageuploads/ Dokumenti/SI-NRP2008-en.pdf.

Romer, P. M. (1990), Endogenous Technological Change. Journal of Political Economy, 98 (5): 71-102. doi:10.1086/261725

SORS (2009), Research and Development Activity, Slovenia, 2008 - Final Data. Available at: http://www.stat.si/eng/novica_prikazi.aspx?id=2742.

SORS (2010a), Research and Development Activity, Slovenia, 2009 - Preliminary Data. Data available on the webpage of the Statistical Office of the Republic of Slovenia. Available at: http://www.stat.si/eng/index.asp. SORS (2010b), Innovation Activity in Manufacturing and Selected Services, Slovenia 2006-2008 - Final Data. Available at: http://www.stat.si/ eng/novica_prikazi.aspx?id $=3447$

SORS (2011a), Database on Innovation. Available at: http://www.stat.si/eng/ tema_ekonomsko_raziskovanje.asp.

SORS (2011b), Database on Education. Available at: http://www.stat.si/eng/ tema_demografsko_izobrazevanje.asp.

SORS (various years), Data available on the webpage of the Statistical Office of the Republic of Slovenia. Available at: http://www.stat.si/ eng/index.asp.

Stare, M. and Bučar, M. (2009), Driving Forces of Innovations towards Services - Inclusive Innovation Policy in the New Member States. Socialiniai mokslai, 1 (63): 7-14.

Stehr, N. (2003), The Social and Political Control of Knowledge in Modern Societies. International Social Science Journal, 55 (178): 643-655. doi:10.1111/j.0020-8701.2003.05504014.x

Švarc, J. (2006), Institucionalne pretpostavke tranzicije u gospodarstvo znanja: karika koja nedostaje. Društvena istraživanja, 15 (3): 319-344.

Tilford, S. and Whyte, P. (2010), The Lisbon Scorecard X: the Road to 2020. Centre for European Reform, http://cer.org.uk/pdf/rp_967.pdf.

Udovič, B. and Bučar, M. (2008), Building the Knowledge Society: The Case of European Union New Member States. Revija za sociologiju, 39 (1-2): 29-49. 
DRUŠ. ISTRAŽ. ZAGREB GOD. 20 (2011), BR. $4(114)$ STR. $967-990$

BUČAR, M.: IS KNOWLEDGE.
World Bank (2011), Knowledge Assessment Methodology, http://web. worldbank.org/WBSITE/EXTERNAL/WBI/WBIPROGRAMS/KFDLP/ EXTUNIKAM/0,,menuPK:1414738 pagePK:64168427 piPK:64168435 $\sim$ theSitePK:1414721,00.html.

\section{Je li društvo znanja vizija ili iluzija? Slučaj Slovenije}

Maja BUČAR

Fakultet društvenih znanosti, Ljubliana

Slovenija je prelazak na gospodarstvo/društvo znanja postavila u središte svoje strategije razvoja, kojom upravljaju globalna ekonomska kretanja i koja je nadahnuta Lisabonskom strategijom EU-a. Uspostava i dobro funkcioniranje nacionalnoga inovacijskog sustava (NIS) percipira se kao glavni instrument slovenske tranzicije u društvo znanja. U članku se analiziraju neki od čimbenika NIS-a i niihov recentni razvoj u ciliu prikazivanja glavnih nedostataka i dostignuća. Provedba glavnih strateških dokumenata usmjerenih prema društvu znanja u zadnjih pet godina daje neujednačenu sliku: na nekim područjima ciljevi su ostvareni, dok na drugima ostaju rupe. U članku se upozorava na problem sposobnosti upravljanja koji se često zaboravlja, a bitan je čimbenik tranzicije. Bez poboljšanja sposobnosti upravlianja, zemlia ne može uspostaviti učinkovit NIS i prijeći u društvo znanja. To upućuje na činjenicu da pretvaranje vizije u stvarnost zahtijeva osjetan napor u poboljšanju sposobnosti upravljanja.

Ključne riječi: društvo/gospodarstvo znanja, nacionalni inovacijski sustav, sposobnost upravljanja, Slovenija

\section{Die Wissensgesellschaft: Vision oder Illusion? Der Fall Slowenien}

Maja BUČAR

Fakultät für Gesellschaftswissenschaften, Ljubljana

Slowenien hat den Übergang zur Wissenswirtschaft/ -gesellschaft in den Mittelpunkt ihrer Entwicklungsstrategie gestellt, die einerseits von globalen Vorgängen im Wirtschaftsbereich abhängig ist und sich andererseits an der Lissabon-Strategie der EU orientiert. Einführung und gutes Funktionieren eines nationalen Innovationssystems werden dabei als die wichtigsten Instrumente der Überleitung Sloweniens zu einer Wissensgesellschaft angesehen. Im vorliegenden Artikel werden bestimmte Faktoren des genannten nationalen Innovationssystems sowie ihre jüngste 
DRUŠ. ISTRAŽ. ZAGREB GOD. 20 (2011) BR. 4 (114)

STR. $967-990$

BUČAR, $M$.

IS KNO'WLEDGE...
Entwicklung analysiert, um die bedeutendsten Ergebnisse, aber auch um Mängel aufzuzeigen. Die in den letzten fünf Jahren erfolgte Umsetzung der wichtigsten, auf den Ausbau der Wissensgesellschaft ausgerichteten Strategiedokumente zeigt einen ungleichmäßigen Verlauf: In bestimmten Bereichen konnten die Ziele erreicht werden, während anderswo noch viele Leerstellen sind. Die Verfasserin verweist auf das oftmals vernachlässigte Problem eines fähigen Managements, das einen wesentlichen Fakłor des Übergangs zur genannten neuen Gesellschaftsform darstellt. Ohne verbessertes Management kann kein nationales Innovationssystem erstellt werden und kann das Land sich nicht zu einer Wissensgesellschaft entwickeln. Daraus ergibt sich zwingend die Erkenntnis, dass die Umsetzung einer Vision in Realität große Anstrengungen erfordert, zumal im Hinblick auf ein verbessertes Management.

Schlüsselbegriffe: Wissensgesellschaft/-wirtschaft, nationales Innovationssystem, kompetentes Management, Slowenien 